\title{
Dictyostelium dimigraformum, Dictyostelium laterosorum and Acytostelium ellipticum: New Acrasieae from the American Tropics
}

\author{
By J. C. CA VENDER \\ Department of Botany, Ohio University, Athens, Ohio 4570I, U.S.A.
}

(Accepted for publication I6 April 1970)

SUMMARY

Two new species of Dictyostelium, $D$. dimigraformum and $D$. laterosorum, and a new species of Acytostelium, A. ellipticum, are described. All three species were first isolated from the surface humus layer of tropical forest soils on the island of Trinidad, W.I. D. dimigraformum is distinguished from other species of the genus by its ability to form both stalkless and stalked migrating pseudoplasmodia. $D$. laterosorum is a member of the cramponbased Dictyostelia. It differs from other members of this group in bearing lateral, sessile sori along the terminal half of the sorophore. A. ellipticum is the second species in the genus Acytostelium to be described. It is distinguished from $A$. leptosomum by its elliptical spores, pattern of aggregation and development, and smaller size.

\section{INTRODUCTION}

As a part of my continuing investigation of forest soils for Acrasieae, I surveyed, during the summer of 1968 , tropical forest soils in Puerto Rico, Trinidad and Tobago, West Indies, and Guyana, South America. Previous investigations indicated that a centre of diversity for Acrasieae exists in the tropics of Central and South America (Cavender \& Raper, I968; Cavender, I 969), as reflected in the several new Acrasieae which have been isolated from this area: Dictyostelium rosarium, D. deminutivum, D. rhizopodium, D. lavandulum, D. coeruleo-stipes, D. vinaceo-fuscum and D. mucoroides var. stoloniferum. Distribution studies have focused on the lowland seasonal evergreen forest which is the optimum forest habitat for Acrasieae in the tropics (Cavender \& Raper, 1968).

On the island of Puerto Rico little such forest remains, consequently most collecting was done in the lower montane forest type prevalent in the Loquillo Experimental Forest. Only seven species and variants were isolated (Table I). Two isolates, one resembling Polysphondylium violaceum in form but lacking pigment, and the other a member of the Dictyostelium mucoroides complex which produces exceptionally numerous sorocarps, are worthy of further study but have not yet been investigated. Possibly the less complex nature of the forests of Puerto Rico compared with those of the South American continent limits the number of Acrasieae species that survive there, or perhaps the island is simply too remote from the continent.

Floristically Trinidad resembles north-eastern South America, a consequence of long union with the continent. The forest vegetation has been studied extensively by J. S. Beard (e.g. I946). Most of the forests sampled are seasonal evergreen; annual 
rainfall 200 to $250 \mathrm{~cm}$. with a dry season from January to May. Mora and crappoguatecare (Carapa-Eschweilera) are the most widespread forest types. I collected from eight sites in the northern part of the island in the vicinity of, and on the lower slopes of, the Northern Range where elevations reach $500 \mathrm{~m}$. Trinidad is an excellent area for Acrasieae. Fourteen species were isolated (Table 1), including the three species described here, which represent approximately $75 \%$ of the known soil Acrasieae. The adjacent island of Tobago supports fewer species of plants because of its greater isolation and smaller size. Less extensive collecting was done there. Only six species were found.

\begin{tabular}{|c|c|c|c|c|}
\hline Species & $\begin{array}{l}\text { Puerto } \\
\text { Rico }\end{array}$ & Trinidad & Tobago & Guyana \\
\hline Dictyostelium mucoroides & $x$ & $x$ & $x$ & $\times$ \\
\hline D. mucoroides variant $\mathbf{I}^{1}$ & $x$ & $x$ & $x$ & $x$ \\
\hline D. mucoroides variant $\mathrm{II}^{2}$ & $x$ & . & . & . \\
\hline D. purpureum & $x$ & $x$ & $x$ & $\times$ \\
\hline D. polycephalum & $x$ & $x$ & . & $x$ \\
\hline D. rhizopodium & . & $x$ & . & $x$ \\
\hline D. vinaceo-fuscum & . & $x$ & . & \\
\hline D. aureum ${ }^{3}$ & . & $x$ & . & $x$ \\
\hline D. minutum ${ }^{4}$ & . & $x$ & . & $x$ \\
\hline D. laterosorum & . & $x$ & $x$ & . \\
\hline D. dimigraformum & . & $x$ & & . \\
\hline Polysphondylium pallidum & $x$ & $x$ & $x$ & $x$ \\
\hline$P$. pallidum variant ${ }^{5}$ & $x$ & & . & $\cdot$ \\
\hline$P$. violaceum & . & $x$ & . & . \\
\hline Acytostelium leptosomum & & $x$ & $x$ & $x$ \\
\hline A. ellipticum & . & $x$ & . & $x$ \\
\hline
\end{tabular}

${ }^{1}$ A delicate, hyaline-spored acrasian common in the tropics.

${ }^{2}$ Similar to the above but producing exceptionally numerous sorocarps.

${ }^{3}$ Golden-yellow sorocarps similar to D. aureum (E. Olive).

${ }^{4}$ In the tropics there are a variety of small hyaline-spored acrasians that resemble D. minutum.

${ }^{5}$ Unpigmented but resembling $P$. violaceum in form.

A limited area in Guyana was sampled-the forests located west of Bartica on the Essequibo River and along Moraballi Creek which are on either red or white sand. They are either mixed forests or consociations with mora, greenheart, morabukea and wallaba as the principal dominants (Davis \& Richards, 1934). Ten species of Acrasieae were isolated (Table I).

Two of the three Acrasieae described are considered new species of the genus Dictyostelium because they have unbranched cellular stalks. The third slime mould has an acellular stalk, consequently it is assigned to the genus Acytostelium.

\section{METHODS}

Soils were collected in small glass vials which hold about $30 \mathrm{~g}$. Leaf mould, humus and some surface mineral soil were taken since these parts of the forest soil profile harbour the greatest number and kinds of Acrasieae (Cavender \& Raper, 1965 b). When I returned to the laboratory the samples were placed at $4^{\circ}$. The isolating technique of Cavender \& Raper (I965a) was used. Developing Acrasieae were transferred 
to dilute hay infusion agar media cross-streaked with Escherichia coli by touching a sorus with a needle and implanting the spores at the intersection of the bacterial streaks (see Raper, 1951). Further studies were carried out either by using this method of cultivation or by 'seeding' the surface of a dilute nutrient agar medium with a suspension of bacteria and spores which was then spread uniformly over the entire agar surface or in a broad band. This is a more favourable method for studying spore germination, aggregation and pseudoplasmodium formation (Raper, 195I). Other agar media used in this study, in addition to the hay infusion, were low nutrient media containing either lactose or dextrose and peptone (LP, DP) in varying amounts and non-nutrient agar supplemented with a pre-grown bacterial food supply.

The amount of growth per day of the slime mould and production of typical fruiting bodies were used as a basis for determining optimum conditions for cultivation. Temperature studies were carried out at 16,20, 22, 25 and $30^{\circ}$. Five different bacteria, Escherichia coli, Aerobacter aerogenes, Pseudomonas fuorescens, Serratia marcescens and Sarcina lutea were tested as food for the Acrasieae using two types of media: (I) non-nutrient agar streaked with pre-grown bacterial samples, and (2) LP or DP agar media streaked with bacterial suspensions. Spores were implanted at the ends of the streaks. Most cellular slime moulds respond best to either $E$. coli or $A$. aerogenes and this was found to be true for the Acrasieae described here.

\section{Dictyostelium dimigraformum Cavender, sp.nov.}

Sorocarpi erecti, vel proni, non ramosi, magnitudine proportioneque varii; in nigritie pseudoplasmodia vaga, typice sine caulibus, in uniducto lumine phototropica, cum caulibus vel sine caulibus; sorophora incolora usque ad leviter flava, usque ad plerumque 3 ad $8 \mathrm{~mm}$. in longitudinem; sori subglobosi usque ad citroformes, plerumque 200 ad $400 \mu \mathrm{m}$. in diametro, lactei usque ad citrini: spori elliptici usque ad reniformes, magnitudine maxime varii, plerumque 7.0 ad $12.0 \times 2.5$ ad $3.5 \mu \mathrm{m}$. sed interdum usque $26 \times 5 \mu \mathrm{m}$.

Habitat: In foliari humo et summo solo, tropica humida silva, Trinidad, W.I.

Typica cultura: AR-5b.

Sorocarps erect or inclined, unbranched, variable in size and proportions, in the dark pseudoplasmodia wandering, typically without producing a stalk, in one-sided light phototropic, migration occurring with or without stalk production; sorophores unpigmented to yellowish, mostly 3 to $8 \mathrm{~mm}$. in length; sori subglobose to citriform, mostly 200 to $400 \mu \mathrm{m}$. in diameter, white to lemon-yellow; spores elliptical to reniform, extremely variable in size, mostly 7.0 to $12.0 \times 2.5$ to $2.5 \mu \mathrm{m}$. but sometimes as large as $26 \times 5 \mu \mathrm{m}$.

Habitat: In leaf mould and surface soil, tropical moist forest, Trinidad, W.I.

Type culture: AR-5b

\section{ISOLATION AND CULTIVATION}

The only isolate of Dictyostelium dimigraformum was obtained from the surface soil of a forest reserve in Trinidad located just above the Asa Wright Nature Centre on the south slope of the Northern Range along the road between Arima and Blanchisseuse. One clone of the organism appeared on the isolation plate.

Dictyostelium dimigraformum was characterized by robust growth but less so than $D$. discoideum, $D$. purpureum or some of the larger strains of $D$. mucoroides. It grew 
well on a variety of media of low nutrient content. Those most often used were $0 . \mathrm{I} \%$ LP and thin hay infusion agar ( $15 \mathrm{~g}$. of dried, leached bluegrass per litre). Optimum growth on these media occurred with Escherichia coli although good growth was obtained with Aerobacter aerogenes and Serratia marcescens. The pigment of $S$. marcescens, prodigiosin, was not digested by the myxamoebae, consequently the slugs and sorocarps were pink to red in colour. Optimum temperature for growth and development was between 20 and $25^{\circ}$. At $16^{\circ}$ growth and development were slow but normal, although much slime was left behind by the migrating slugs. No growth occurred at $30^{\circ}$ but growth and differentiation proceeded normally at $28^{\circ}$.

\section{Growth and morphogenesis}

Spore germination. Germination took place in 4 to $5 \mathrm{~h}$. when spores were spread on $0.1 \%$ LP medium. The germination process was similar to that described for Dictyostelium discoideum by Cotter \& Raper (I968). The swelling spore (Pl. I, fig. I) in some cases approached spherical proportions before pressure from within caused the cellulose wall to split and allowed the myxamoeba to emerge (Pl. I, fig. 2). The slime surrounding spores removed from a sorus dried very quickly making them difficult to spread on the agar surface without leaving clumps. Some such clumps of several hundred or more spores germinated en masse (Pl. I, fig. 6). Aggregation and culmination followed without an intervening growth phase. However, this refruiting habit did not occur to the extent described for D. mucoroides var. stoloniferum (Cavender \& Raper, 1968). An interesting characteristic found in D. dimigraformum was the range in spore size. Spores are elliptical in shape, occasionally reniform. Most spores are 7 to $12 \times 2.5$ to $3.5 \mu \mathrm{m}$. with a mean of $8.0 \times 3.0 \mu \mathrm{m}$. Spores I 5 to $18 \mu \mathrm{m}$ in length were not uncommon (Pl. I, fig. 4); larger spores were rare but one measured $26 \times 5 \mu \mathrm{m}$. (Pl. I, fig. 5). Spores of different size ranges are known for D. discoideum and for the crampon-based Dictyostelia (Raper \& Fennell, 1967), but this is the first report of such extreme variation in spore size in Acrasieae. Sussman\& Sussman (I962) found a relationship between ploidy and spore size in $D$. discoideum.

Vegetative growth. The myxamoebae appeared similar to those of Dictyostelium discoideum or D. mucoroides (P1. I, fig. 3). Variation in size was apparent from spore dimensions. Shape changed during the life-cycle: while feeding, myxamoebae were circular in outline with diameters averaging about I I $\mu \mathrm{m}$.; while moving, they elongated to about $20 \times 10 \mu \mathrm{m}$. This elongation was even more exaggerated when the myxamoebae entered an aggregation stream.

Aggregation. In a culture prepared by inoculating the surface of $0 . \mathrm{I} \% \mathrm{LP}$ medium with a mixture of Escherichia coli and slime mould spores, aggregation began after available bacteria had been consumed. At $25^{\circ}$ this period was about $40 \mathrm{~h}$. for Dictyostelium dimigraformum. Centres were spaced at an average density of $6 / \mathrm{cm} .{ }^{2}$ on darkgrown plates. In the light the density was greater. Almost $100 \%$ of the myxamoebae entered the aggregates. Streams appeared before actual centres could be detected and were often flat and sheet-like at this stage. Wheel-like aggregations soon developed, each with a definite centre or hub and well-defined streams or spokes (Pl. 1, fig. 7). A later stage had fewer but larger streams (Pl. 2, fig. 9). Usually one pseudoplasmodium or slug was formed from each centre. Where myxamoebae were very dense and large centres were formed, several slugs might emerge.

Pseudoplasmodia. When a culture plate was illuminated from above, sorocarps were 
constructed vertically from the point of aggregation (P1. 2, fig. I4). If grown with onesided illumination, some slugs moved away from the point of aggregation and a prostrate stalk was formed as the slug migrated (PI. I, fig. 8). The occasional production of a stalkless slug (Pl. 2, fig. I I) distinguished this species from all those with stalkforming slugs. The stalkless-slug left behind as a trail only the collapsed slime case that is continually secreted. This slug, identical in appearance and behaviour to its counterpart in the life-cycle of Dictyostelium discoideum, was especially abundant on $0 . \mathrm{I} \%$ LP medium and much less abundant on buffered hay infusion agar. In absolute darkness most slugs were stalkless. They might wander over the agar surface for a week or more before sorocarp formation occurred, but sorocarp formation could be initiated dramatically by exposing the culture to overhead light.* Slugs then stopped moving and within $\mathrm{I}$ to $2 \mathrm{~h}$. became orientated on a vertical axis, and somewhat flattened to a pear shape (Pl. 2, fig. I2) as the internally formed stalk made contact with the agar surface (Pl. 2, fig. Io). As the stalk lengthened, the mass of cells left the substratum, perhaps partially through the individual efforts of the myxamoebae but principally through the force exerted by the lengthening stalk (Raper \& Fennell, 1952).

A dark-grown slug might form a length of stalk and then cease stalk formation while continuing to migrate. The environmental factors which 'trigger' stalk formation in the dark are not known. Sorocarps that were formed were generally on the sides of the Petri dish, indicating that a decreasing relative humidity might act as a trigger as it does for other acrasians such as Dictyostelium discoideum.

Migrating slugs produced well-defined slime tracks often (especially at temperatures below $20^{\circ}$ ) leaving behind clumps of cells which occasionally formed small slugs or fruiting bodies (PI. I, fig. 8).

Sorocarps. The formation of sorocarps was not studied cytologically but appeared to follow closely the pattern described for Dictyostelium discoideum by Raper \& Fennell (I952) except that a basal disc was not formed. Sorocarps varied greatly in size and orientation depending upon the density of myxamoebae and the availability and direction of light. Commonly, when produced on LP medium after a period of migration, they resembled the upright portions of sorocarps of D. purpureum or larger members of the D. mucoroides complex. The unbranched, tapering, upright stalk, 3 to $8 \mathrm{~mm}$. high, usually had a short supporting horizontal portion surrounded by slime (Pl. 2, fig. I3). The terminal sori were globular or citriform, their diameters (usually proportional to the stalk length) most commonly 200 to $400 \mu \mathrm{m}$. The sori often developed an intense lemon-yellow colour derived from the pigmentation of the spores, but this did not always develop, and a gradation in colour from cream-white to lemon-yellow was found in most cultures.

Dictyostelium laterosorum Cavender, sp.nov.

Sorocarpi typice erecti vel proni, interdum procidui, non saepe ramosi, magnitudine proportioneque varii; sorophora caesia usque leviter violacea, saepe subbruna, plerumque 5 ad $10 \mathrm{~mm}$. in longitudinem sed ex I $\mathrm{mm}$. usque $20 \mathrm{~mm}$. varia, sorophorum basi exiliter digitatae et instar claviculae; sori globosi, caesii usque leviter violacei, saepe subbruni, et ad laterales et terminales in positionibus, laterales sori plerumque minores, sessiles, 80 ad $150 \mu \mathrm{m}$. in diametro, I ad 10 in numero, terminales sori

* Light induction of sorocarp formation was recently discovered for $D$. discoideum by Newell, Telser \& Sussman (1969). 
I $30 \mathrm{ad} 200 \mu \mathrm{m}$. in diametro; spori varii, elliptici, reniformes vel recurvi, 6.0 ad $\mathrm{I} 3.0 \times$ 2.5 ad $4.0 \mu \mathrm{m}$.

Habitat: In foliari humo et summo solo, tropica humida silva, Trinidad et Tobago, W.I.; Colombia, S.A.

Typica cultura: TB I I-I

Sorocarps typically erect or inclined, sometimes prostrate, infrequently branched, variable in size and proportions, sorophores bluish grey to light violet, often with a brownish cast, usually 5 to $10 \mathrm{~mm}$. in length but varying from I to $20 \mathrm{~mm}$.; sorophore bases weakly digitate and crampon-like; sori globose, bluish grey to light violet often with a brownish cast, both lateral and terminal in position, lateral sori smaller, sessile 80 to $\mathrm{I} 50 \mu \mathrm{m}$. in diameter, $\mathrm{I}$ to $\mathrm{Io}$ in number, terminal sori $\mathrm{I} 30$ to $200 \mu \mathrm{m}$. in diameter; spores variable in shape and size, elliptical, reniform or recurved, 6.0 to $13.0 \mu \mathrm{m} . \times 2.5$ to $4.0 \mu \mathrm{m}$.

Habitat: Leaf mould and surface soil, tropical moist forest, Trinidad and Tobago, W.I.; Colombia, S.A.

Type culture: TB I I-I

\section{Isolation and cultivation}

Initially two isolations of this species were made, strain TB I I-I from semi-deciduous forest on the north slope of the Main Ridge, Tobago, along the road from Roxborough to Charlotville, and strain AE-4 from seasonal evergreen forest near Arena, Trinidad. Three other isolations have subsequently been made from Colombia. Excellent growth and development of Dictyostelium laterosorum was obtained at 22 to $25^{\circ}$ on $0.1 \% \mathrm{LP}$ or hay infusion agar media in association with Escherichia coli or on non-nutrient agar streaked with pre-grown bacteria.

\section{Growth and morphogenesis}

Spores and myxamoebae. Spores gave rise to myxamoebae after 4 to $5 \mathrm{~h}$. at $25^{\circ}$ on LP medium. A large percentage failed to germinate. Spores of the two strains TB I I-I and AE-4 were originally different in shape and size; strain TB I I-I produced predominantly elliptical spores 6 to $9 \times 2.5$ to $4 \mu \mathrm{m}$. (Pl. 3, fig. I7); strain AE-4 produced larger spores, 9 to $13 \times 3.5$ to $4.5 \mu \mathrm{m}$., mostly reniform or recurved in shape (Pl. 3, fig. I6). After about eight months of laboratory cultivation diploidization apparently occurred. Strain TB I I-I began producing spores similar in size and shape to those of AE-4 (Pl. 3, fig. I8); other differences between the two strains remained constant.

The myxamoebae were distinguishable from those of Dictyostelium dimigraformum by their elongated triangular shape while moving (Pl. 3, fig. 19), the relatively broad front advancing, the tapering apex trailing behind. This posterior apex might be as long as the body of the myxamoeba, so narrow that it was just visible when magnified $\times 600$, and occasionally it was forked. Up to five peripheral nucleoli were conspicuous in the nucleus. Feeding myxamoebae were circular in outline, their diameters mostly io to $\mathrm{I} 5 \mu \mathrm{m}$.

On LP medium aggregation began after the bacteria had been consumed by the myxamoebal population. At $25^{\circ}$ this period was $c .42 \mathrm{~h}$. for strain AE-4 and $c .45 \mathrm{~h}$. for strain TBII-I. The two strains differed somewhat in their patterns of aggregation. Myxamoebae of strain AE-4 tended to develop strong wheel-like centres without delay (Pl. 3, fig. 23), whereas those of strain ТВ I I-I did not form definite centres immediately 
but first formed small clumps or mounds (PI. 3, fig. 20) which gradually increased in size (Pl. 3, fig. 2I). Some of these early aggregations developed short streams. After $72 \mathrm{~h}$. certain centres had become dominant and attracted myxamoebae from most of the early aggregations (Pl. 3, fig. 22), though the radiate pattern exhibited by AE-4 did not often develop (Pl. 4, fig. 24) and the streams often broke up into numerous smaller centres, especially when aggrgeation occurred in the light.

Pseudoplasmodia and sorocarp formation. Dictyostelium laterosorum typically produced pseudoplasmodia that constructed stalks vertically or at an angle from the aggregation centre although the somewhat larger Colombian strains were prone to wander over the agar surface. The phototropic response was not particularly strong although one-sided illumination induced migration toward the light. Light is not essential for completion of the life-cycle.

The rising sorogen resembled that of Dictyostelium mucoroides during the early stage, but as the terminal half of the stalk was formed masses of myxamoebae were periodically abstricted from the posterior portion (Pl. 4, fig. 28). These myxamoebae differentiated into spore cells without concomitant formation of lateral stalks as in Polysphondylium (Pl. 4, fig. 26). The result was a series of sessile globular sori which gave the sorocarp a beaded appearance (Pl. 4, fig. 29). This method of increasing the efficiency of spore distribution was first discovered in the slime mould Dictyostelium rosarium (Raper \& Cavender, 1968). D. laterosorum closely resembled this species in the nature and disposition of the sori. Occasionally a lateral branch bearing a sorus at the tip ( $\mathrm{Pl} .4$, fig. 30) was seen. The masses of abstricted myxamoebae occasionally retained the capacity to construct a stalk. Sorocarps may have up to ten or more lateral sori, each 80 to $150 \mu \mathrm{m}$. in diameter, though the terminal sorus is slightly larger ( 130 to $200 \mu \mathrm{m}$.).

The pigmentation of the sorocarps approximated that of Dictyostelium lavandulum (Raper \& Fennell, 1967), i.e. bluish grey deepening with age to light violet or lavender, often with a brownish cast.

The sorocarps were supported by a crampon base enveloped by a layer.of supporting slime material (Pl. 4, fig. 27). The ramifications of the crampon, much less developed than in Dictyostelium rhizopodium, were short cellular extensions, often knob-like, protruding from the expanded base of the stalk (Pl. 4, fig. 25). Of other Acrasieae these crampons resembled most closely the expanded base type of $D$. coeruleo-stipes (Raper \& Fennell, 1967).

Sorocarps have a broad size range. Lengths of mature stalks varied from I to $20 \mathrm{~mm}$. but most were 5 to $10 \mathrm{~mm}$. Strain AE-4 produced more large, rangy sorocarps with a greater proportion of stalk to spore mass than strain TB I I-I. Some of the Colombian strains also had this habit but produced more lateral sori than AE-4.

Acytostelium ellipticum Cavender, sp.nov.

Sorocarpi maxime delicati, solitarii vel gregarii, $200 \mathrm{ad} 1000 \mu \mathrm{m}$. in altitudinem; sorophora incolora, acellularia, I ad $2 \mu \mathrm{m}$. in diametro attenuata usque $<\mathrm{I} \cdot 0 \mu \mathrm{m}$. in extrema parte; surgens sorogen ventricosa-rostrata; sori globosi, 18 ad $40 \mu \mathrm{m}$. in diametro; spori elliptici, 5.5 ad $8.0 \mu \mathrm{m} . \times 2.0$ ad $3.0 \mu \mathrm{m}$.

Habitat: In foliari humo et summo solo, tropica humida silva, Trinidad, W.I.; Guyana, Colombia, S.A.

Typica cultura: AE-2 
Sorocarps extremely delicate, solitary or gregarious, 200 to $1000 \mu \mathrm{m}$. in height; sorophores unpigmented, acellular, $\mathrm{I}$ to $2 \mu \mathrm{m}$. in diameter tapering to less than $\mathrm{I} \cdot 0 \mu \mathrm{m}$. at the tip; rising sorogen ventricose-rostrate; sori globose, 18 to $40 \mu \mathrm{m}$. in diameter; spores elliptical, 5.5 to $8.0 \mu \mathrm{m} \times 2 \cdot 0$ to $3.0 \mu \mathrm{m}$.

Habitat: Leaf mould and surface soil, tropical moist forest, Trinidad, W.I.; Guyanas Colombia, S.A.

Type culture: AE-2

\section{Isolation and cultivation}

Acytostelium ellipticum was isolated from the Trinidad Government Forest Reserves at Melajo and Arena, from the lowland forest along Moraballi Creek in Guyana, and more recently from the Amazon Basin of Colombia. The isolates were very small and delicate, barely visible on the isolation plates at $\times 30$ magnification, and so considerably smaller than those of $A$. leptosomum on the same isolation plates. Cultivation was originally attempted on $0.1 \%$ LP medium streaked with Escherichia coli. Germination and growth occurred with no further morphogenesis. Weak hay infusion medium ( $8 \mathrm{~g}$. dried leached bluegrass $/ 1$.) with $E$. coli gave good growth and development. After several months cultivation the slime mould was able to complete its life-cycle on $0.1 \% \mathrm{LP}$, but optimum growth and development occurred on a weak glucose-peptone medium ( $0.05 \%$ glucose and $0.025 \%$ peptone) at 20 to $25^{\circ}$ when a suspension of $E$. coli and slime mould spores was spread in a broad band on the agar. E. coli and Aerobacter aerogenes were the best food sources. No development took place at $30^{\circ}$.

\section{Growth and development}

The elliptical spores measured $5 \cdot 5$ to $8 \cdot 0 \times 2 \cdot 0$ to $3 \cdot 0 \mu \mathrm{m}$. (Pl. 5, fig. 31 ). After germination the myxamoebae formed a densely packed feeding front (Pl. 5, fig. 32). On DP medium inoculated with a suspension of spores and Escherichia coli the bacteria were consumed after $40 \mathrm{~h}$. at $25^{\circ}$. The myxamoebae then clumped together (Pl. 5, fig. 32) in increasing numbers without streaming, to form small mounds (PI. 5, fig. 35). Crude streams were observed only when a culture was cooled to $4^{\circ}$ or on a medium of higher nutrient content $(0.25 \%$ DP) (Pl. 5, fig. 34) on which subsequent development was abnormal. The aggregation pattern therefore differs from Acytostelium leptosomum (Pl. 5, fig. 40), where radiate streaming occurs. Each mound-like aggregation produces one to several sorocarps ( $\mathrm{Pl}$. 5, fig. 38 ) depending upon its size: the highly gregarious fruiting of $A$. leptosomum (Pl. 5, fig. 40) does not occur. The developing sorogen is long and tapered (Pl. 5, fig. 33), and as the stalk lengthens it develops a bulbous posterior portion (Pl. 5, fig. 36); in contrast, the developing sorogens of A. leptosomum are naviculate (Pl. 5, fig. 40). The cells in the narrow anterior portion of the A. ellipticum sorogen probably secrete the acellular stalk tube: Raper \& Quinlan (I958) found that in the sorogen of $A$. leptosomum the myxamoebae in the anterior end were arranged perpendicular to the stalk, indicating a secretory rather than a locomotive function. Following aggregation, secretion of the entire stalk (200 to $1000 \mu \mathrm{m}$. in length) took 2 to $3 \mathrm{~h}$. Its delicate nature in respect to the mass of spores which it supported (Pl. 5, fig. 39) was an engineering wonder. A globular unpigmented sorus ( 18 to $40 \mu \mathrm{m}$. across) developed at the terminus of the stalk (Pl. 5, fig. 37). The average dimensions of both stalk length and sorus were less than for A. leptosomum. 


\section{DISCUSSION}

Of the three new Acrasieae described here, perhaps Dictyostelium dimigraformum is of greatest interest because it possesses characteristics intermediate between those of $D$. mucoroides and $D$. discoideum. Its similarity to $D$. discoideum is most apparent in the migrating pseudoplasmodial phase of development when stalk formation does not occur. This is a more efficient means of migration than we find in $D$. mucoroides since cells are not needlessly expended. My observations concerning the response of the pseudoplasmodia to light essentially duplicate those of Newell et al. (1969) working with $D$. discoideum. The myxamoebae show a physiological similarity to those of $D$. discoideum since they are unable to digest the pigment prodigiosin. Myxamoebae of $D$. mucoroides digest this pigment. The sorocarps themselves as well as the stalked migrating pseudoplasmodia resemble those produced by $D$. mucoroides or $D$. purpurem. The organism provides good experimental material for the study of environmental factors which initiate stalk formation. The 17 -fold variation in size of the spores of $D$. dimigraformum is of interest, for it has been argued that genetic heterogeneity brought about through para-sexual mechanisms is basic to cell differentiation in the Acrasieae (Ashworth \& Sackin, 1969). The possible role which these large cells play in development is worthy of investigation.

Dictyostelium laterosorum has the beaded sorocarps of D. rosarium but differs from this species in pigmentation, spore shape, crampon base, and developmental pattern (see Raper \& Cavender, I968). D. laterosorum also resembles D. lavandulum in pigmentation of the sorocarps and the presence of a crampon base. The crampon-based Acrasieae are tropical in distribution. Hopefully, Coenonia, a crampon-based genus which is more highly differentiated than any cellular slime mould now in culture, will someday turn up in tropical soils.

Acytostelium ellipticum is one of the smallest Acrasieae. The sorocarps are more delicate than those of Dictyostelium deminutivum but the myxamoebae are larger. The pattern of aggregation and sorocarp distribution is closer to this species than to A. leptosomum.

Strains AR-5b, TBII-I and AE-2 have been deposited with the American Type Culture Collection, Washington, D.C.

This investigation was supported by a National Science Foundation COSIP grant to Wabash College.

The writer is indebted to John B. Thurston for aid in collecting the soils and in isolating Acrasieae from them.

\section{REFERENCES}

Ashworth, J. M. \& SACKin, M. J. (1969). Role of aneuploid cells in cell differentiation in the cellular slime mould Dictyostelium discoideum. Nature, London 224, 817-818.

BEARD, J. S. (1946). The mora forests of Trinidad, British West Indies. Journal of Ecology 33, 173-I92.

Cavender, J. C. (1969). The occurrence and distribution of Acrasieae in forest soils. II. East Africa. American Journal of Botany 56, 993-998.

CAvender, J. C. \& RAPER, K. B. (1965a). The Acrasieae in nature. I. Isolation. American Journal of Botany 52, 294-296.

Cavender, J. C. \& Raper, K. B. $(1965 b)$. The Acrasieae in nature. II. Forest soil as a primary habitat. American Journal of Botany 52, 297-302. 
Cavender, J. C. \& Raper, K. B. (I968). The occurrence and distribution of Acrasieae in forests of sub-tropical and tropical America. American Journal of Botany 55, 504-513.

CotTer, D. A. \& RAPER, K. B. (1968). Properties of germinating spores of Dictyostelium discoideum. Journal of Bacteriology 96, I680-1689.

Davis, T. A. W. \& Richards, P. W. (1934). The vegetation of Moraballi Creek, British Guiana; an ecological study of a limited area of tropical rain forest. Journal of Ecology 22, I06-1 55.

Newell, P. C., Telser, A. \& Sussman, M. (1969). Alternative developmental pathways determined by environmental conditions in the cellular slime mould Dictyostelium discoideum. Journal of Bacteriology 100, 763-768.

RAPER, K. B. (195I). Isolation, cultivation, and conservation of simple slime moulds. Quarterly Review of Biology 26, 169-190.

RAPER, K. B. \& CAVEnder, J. C. (1968). Dictyostelium rosarium: A new cellular slime mould with beaded sorocarps. Journal of Elisha Mitchell Scientific Society 84, 3I-47.

Raper, K. B. \& Fennell, D. I. (1952). Stalk formation in Dictyostelium. Bulletin of the Torrey Botanical Club 79, 25-5I.

RAPER, K. B. \& Fennell, D. I. (1967). The crampon-based Dictyostelia. American Journal of Botany 54, 515-529.

RAPER, K. B. \& Quinlan, M. S. (I958). Acytostelium leptosomum: a unique cellular slime mould with an acellular stalk. Journal of General Microbiology 18, 16-32.

Sussman, M. \& Sussman, R. R. (1962). Ploidal inheritance in Dictyostelium discoideum. I. Stable haploid, stable diploid and metastable strains. Journal of General Microbiology 28, 4I7-429.

\section{EXPLANATION OF PLATES}

Plate I

\section{Dictyostelium dimigraformum}

Fig. I. A germinating spore just before the splitting of the spore wall. $\times$ I140.

Fig. 2. The same germinating spore. A myxamoeba is emerging from the split spore case. $\times$ I I 40 .

Fig. 3. A moving myxamoeba. $\times$ I I 40 .

Fig. 4. Spores, including a large one $17 \mu \mathrm{m}$. in length. $\times 1140$.

Fig. 5. A very large spore, $26 \mu \mathrm{m}$ in length. $\times 900$.

Fig. 6. A pseudoplasmodium forming from a clump of spores which have germinated en masse. Some of the myxamoebae are wandering away. $\times 70$.

Fig. 7. A typical wheel-like aggregation. $\times 29$.

Fig. 8. A migrating pseudoplasmodium which is producing a stalk. Note the partially dried sorogen which developed from myxamoebae cast off in the slime track of a stalkless migrating slug. $\times 90$.

\section{Plate 2}

\section{Dictyostelium dimigraformum}

Fig. 9. An aggregation at a slightly later stage in development from that in Pl. I, fig. $7 . \times 35$.

Fig. 10. A pseudoplasmodium which has stopped migration after exposure to light and which is producing a stalk, visible in the interior. $\times 58$.

Fig. II. A stalkless migrating pseudoplasmodium or slug. $\times 58$.

Fig. 12. A pseudoplasmodium which has ceased migration and become orientated almost vertically. The pre-spore mass is about to be lifted off the agar surface. $\times 100$.

Fig. I3. A mature sorocarp produced from a stalkless migrating pseudoplasmodium. Note the short horizontal portion surrounded by slime. $\times 44$.

Fig. 14. A small rising sorogen. The stalk is composed of a single row of cells. $\times 35$.

Fig. 15. Mature sorocarps, which have developed without migration, collapsed on the agar surface. $\times 5$. 
Journal of General Microbiolog!, Vol. 62, No. 1

Plate I
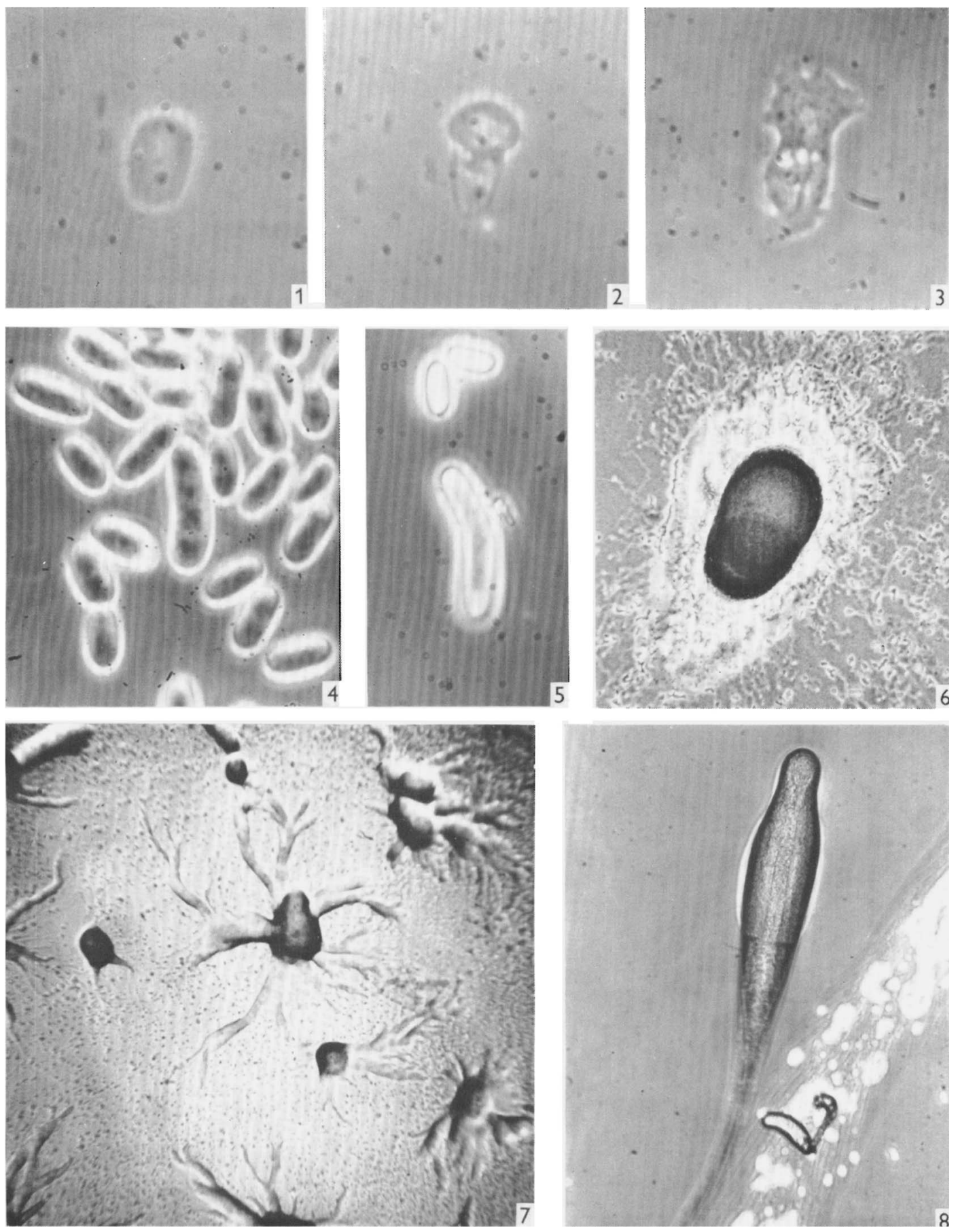

I. C. CAVENDIR

(1acing p. 122) 
Journal of General Microbiology, Vol. 62, No. 1

Plate 2
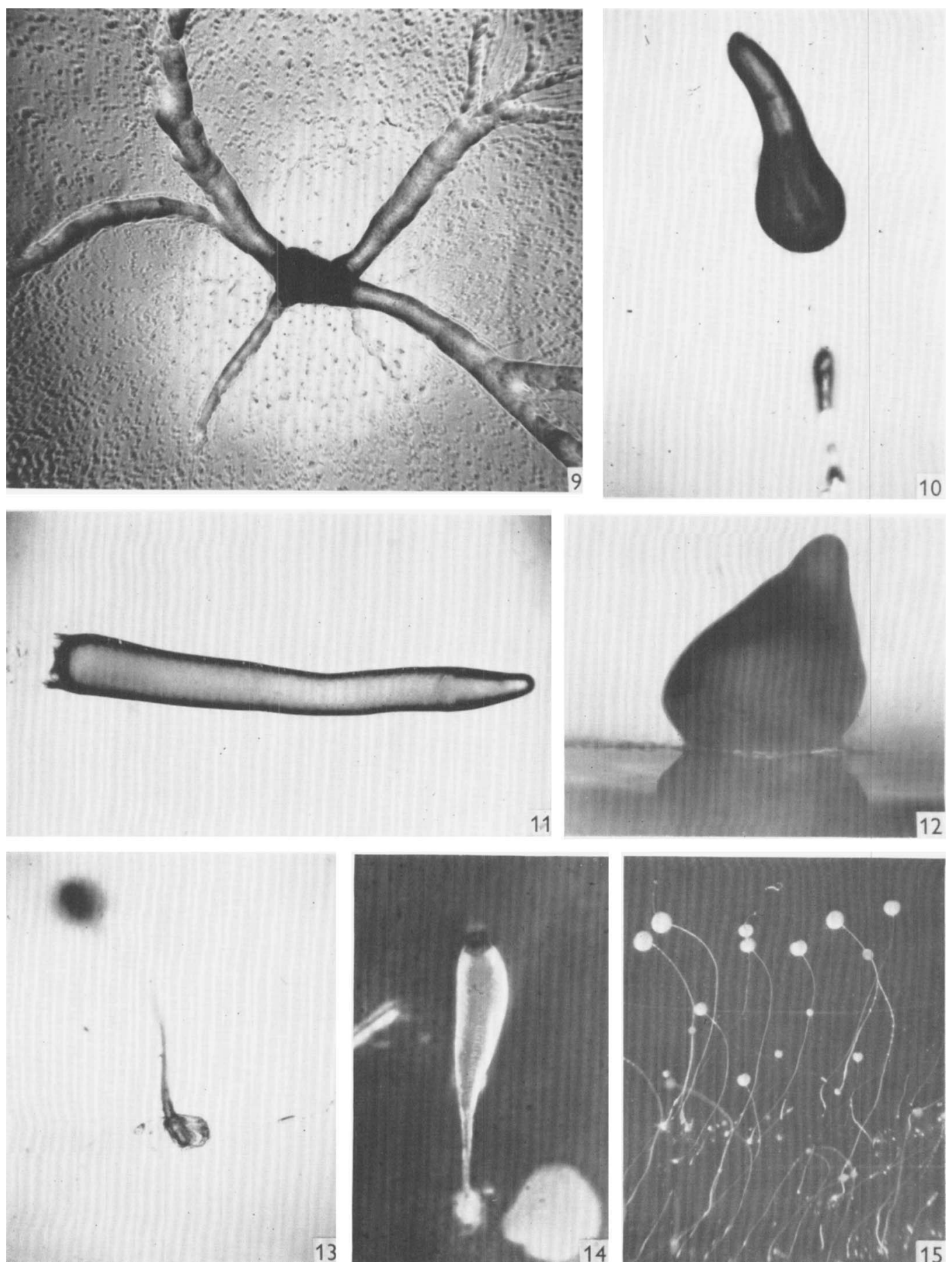

J. C. CAVENDER 
Journal of General Microbiologl, Vol. 62, No. I

Plate 3
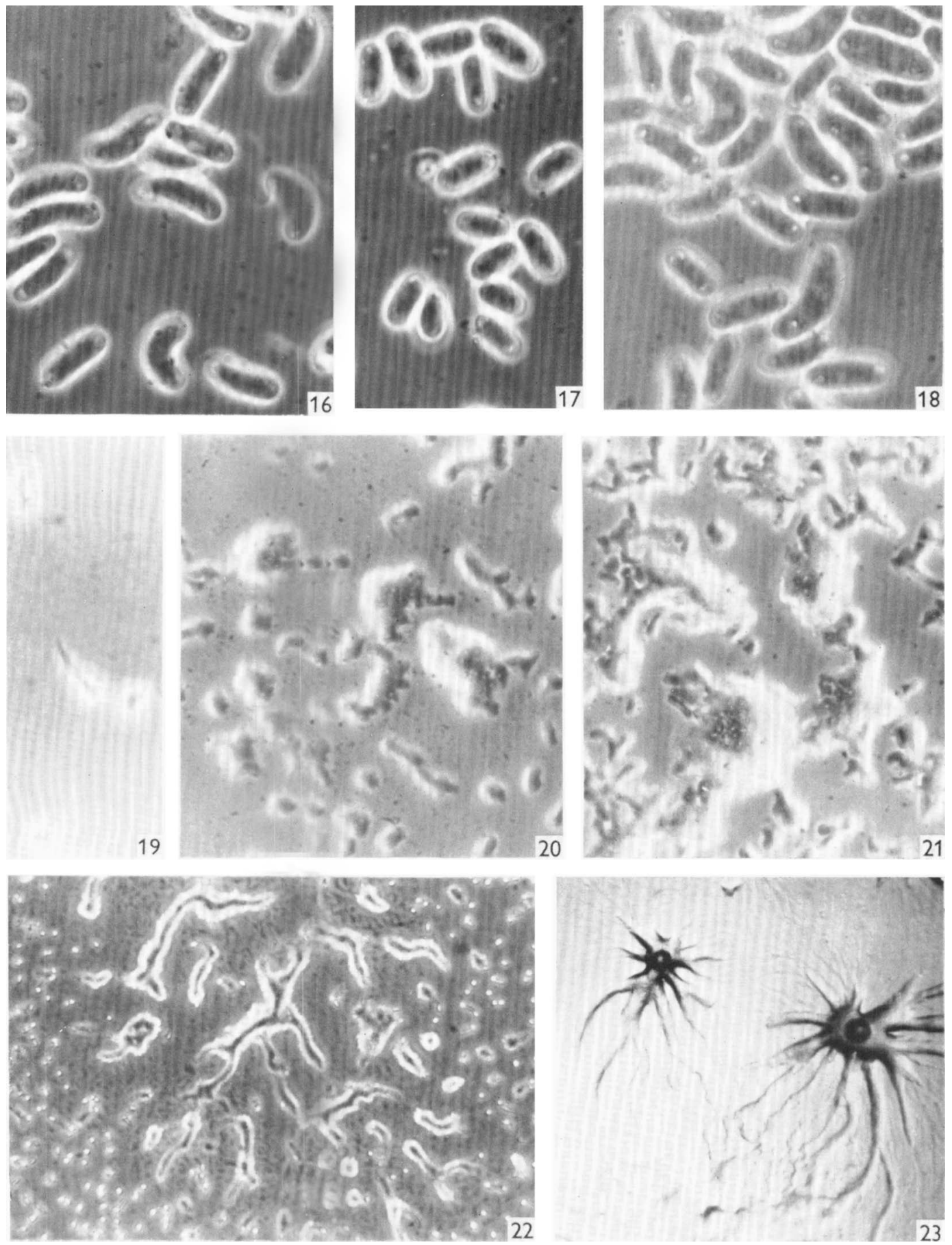
Journal of General Microbiology, Vol. 62, No. I

Plate 4
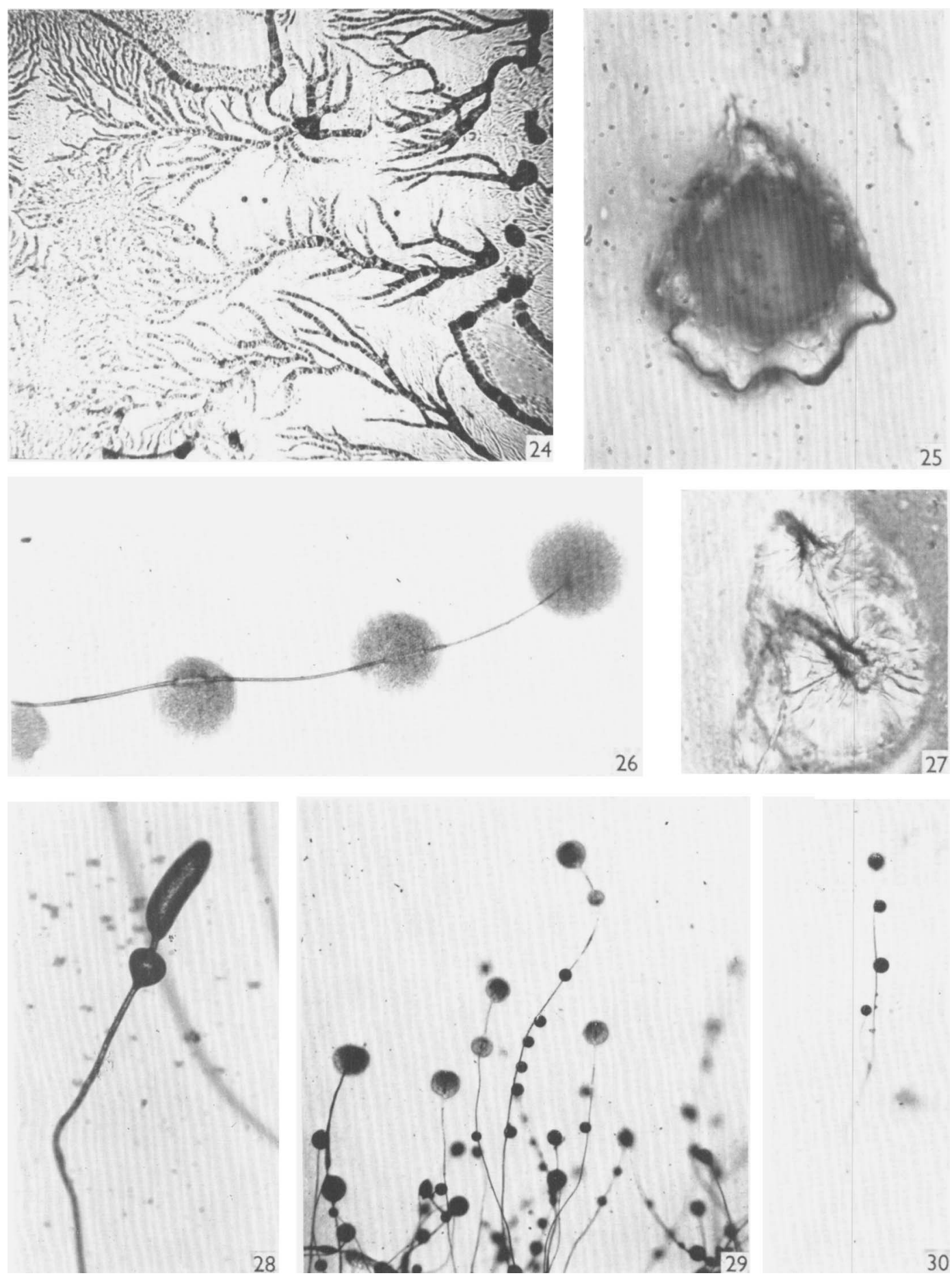

J. C. CAVENDER 

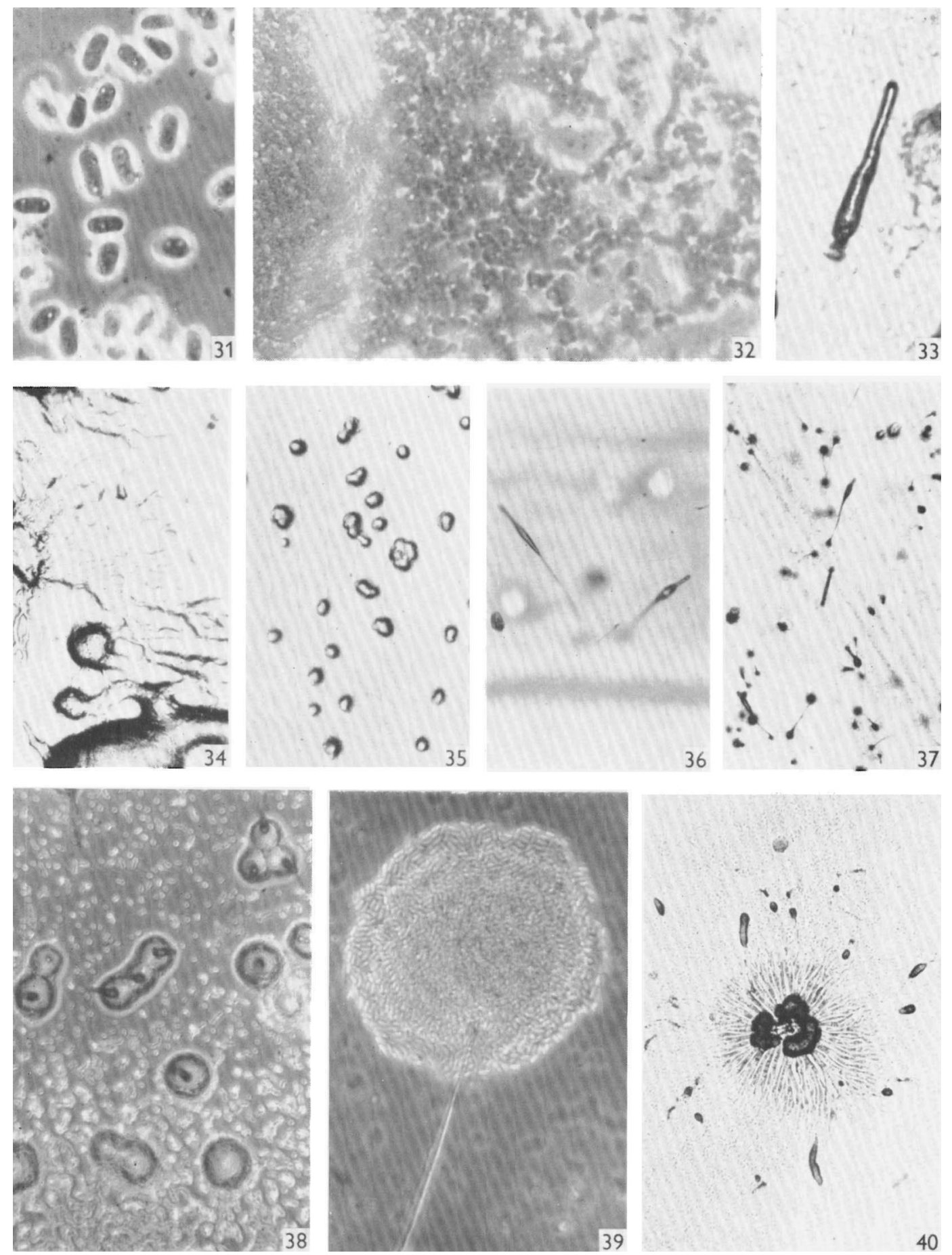

I. C. CAVENDER 
Plate 3

Dictyostelium laterosorum

Fig. 16. Spores of strain AE-4. Note the granules at each end. $\times$ I 140 .

Fig. 17. Spores of strain TB I I-I before size change. $\times$ II40.

Fig. I8. Spores of strain TB II-I after size change. $\times$ I I 40 .

Fig. 19. The central myxamoeba is moving toward the lower right. Note the triangular shape and long tail. $\times 450$.

Fig. 20. TB I I-1. An early stage in aggregation. The cells have gathered into small clumps. $\times 340$.

Fig. 2I. TB I I-I. A slightly later stage. The clumps have increased in size. $\times 290$.

Fig. 22. TB II-I. An intermediate stage in aggregation. Dominant centres are forming which attract the myxamoebae from surrounding clumps. $\times 115$.

Fig. 23. Wheel-like aggregates typical of strain AE-4. $\times 29$.

Plate 4

\section{Dictyostelium laterosorum}

Fig. 24. TB I I-I. A late stage in aggregation. Strong centres have developed which attract myxamoebae from a relatively large area. $\times 9$.

Fig. 25. A typical crampon-like base which supports the sorocarp. $\times 450$.

Fig. 26. Terminal portion of the sorocarp showing the disposition of the sori. $\times 46$.

Fig. 27. The expanded disc of slime material which surrounds the base of the stalk. $\times 115$.

Fig. 28. A developing sorogen which has just abstricted a mass of myxamoebae from its posterior portion. The myxamoebae will differentiate into spores forming together a lateral sorus. $\times 53$.

Fig. 29. Mature sorocarps showing the typical beaded appearance. $\times 23$.

Fig. 30. A sorocarp on which a lateral branch has developed. $\times 23$.

\section{Plate 5 \\ Acytostelium ellipticum}

Fig. 3I. Spores showing the characteristic shape for the species. $\times 1140$.

Fig. 32. Myxamoebae densely packed in a feeding front at the left. At the right aggregation is beginning to occur. $\times 290$.

Fig. 33. Characteristic shape for the species of a young rising sorogen. $\times 230$.

Fig. 34. Rudimentary stream formation by strain AE-2 on $0.25 \%$ dextrose- $0.25 \%$ peptone agar. Subsequent development was abnormal. $\times 29$.

Fig. 35. Typical aggregates formed on $0.25 \%$ dextrose $-0.05 \%$ peptone agar. $\times 29$.

Fig. 36. Rising sorogens. At this stage the sorogen has a relatively long narrow anterior portion and a more bulbous posterior. $\times 92$.

Fig. 37. Sorocarps at various stages of development. $\times 46$.

Fig. 38. Aggregates from which I to 3 sorocarps are developing. $\times 92$.

Fig. 39. Terminal portion of a mature sorocarp collapsed on the agar surface. Note the dimension of the stalk tube in relation to the spore mass it supported. $\times 290$.

Fig. 40. A typical aggregate of $A$. leptosomum showing stream formation, numerous clustered sorocarps and naviculate sorogens. $\times 23$. 